\title{
Measuring Equality: \\ A Comparative Perspective on Women's Legal Capacity and Constitutional Rights in Five Commonwealth Countries*
}

\author{
Marsha A. Freeman $\dagger$
}

\section{INTRODUCTION}

In the twentieth century, women have had the unique historical opportunity to work for-and sometimes win-a guarantee of equal rights in their countries' constitutions. ${ }^{1}$ The essential question in deter-

- The research for this article was made possible with the cooperation of Arvonne Fraser, Senior Fellow at the Humphrey Institute of Public Affairs and valued colleague. The author is grateful to her and to Stephen Isaacs of Columbia University and Mary Martin, formerly of the Humphrey Institute, for helpful comments and encouragement. Gratitude also is extended to friends and colleagues who helped the author make a beginning in understanding the complexities of sub-Saharan African culture and customary law: Bart Rwezaura, Alice Armstrong, Athaliah Molokomme, Gladys Mutukwa, Pat Mahmoud, and Margaret Rogers. Christine Wilson of the Foreign and Commonwealth Office Library in London, the reference librarians at the University of Minnesota Law School and the Africana Collection at Northwestern University, and Dr. Eileen Boxill of the Jamaica Law Reform Commission also were of great help. The acquisition of research materials was made possible in part by a grant from the Carnegie Corporation, which focuses activities on countries of the Commonwealth Caribbean and sub-Saharan Africa. Any errors in discussing these matters are purely those of the author.

† Fellow, Humphrey Institute of Public Affairs, University of Minnesota; Deputy Director, International Women's Rights Action Watch. B.A., University of Minnesota, 1968; Ph.D., University of Pennsylvania, 1975; J.D., University of Minnesota, 1976.

1 New constitutions have been produced as a result of revolutions, peaceful political change, or independence from colonial rule (in some countries, all these circumstances have occurred in a short time). Gender equality has been an important consideration in a number of revolutionary constitutions. See, for example, Nicaraguan Const, Arts 27, 73 (1987); Cuba Const, Ch III, Art 35, Ch V, Arts 40, 41 (1976); Mozambique Const, Arts 26, 29 (1975). In some countries women's roles in their revolutions represented a major departure from prior roles of dependency; the revolution allowed for-and even required-new roles. See generally, Debra Evenson, Women's Equality in Cuba: What Difference Does a Revolution Make?, $4 \mathrm{~J}$ I \& Inequal 295 (1986); Ruth Weiss, The Women of Zimbabwe 105-15 (Kesho, 1986). In Brazil and Canada, as a result of women's organizational efforts, the new constitutions include specific provisions concerning gender equality. Silvia Pimentel, A Comparative Study of the U.N. Convention on the Elimination of All Forms of Discrimination Against Women, the Brazilian Women's Proposals to the National Consituent Assembly, and the 1988 Brazilian Constitution (1988) (available from the Intl Women's Rights Action Watch); Katherine J. de Jong, Sexual Equality: Interpretation of Section 28, in Ann F. Bayefsky and Mary A. Eberts, eds, Equality Rights and the Canadian Charter of Rights and Freedoms 493 (Carswell, 1985). 
mining the value and the success of these efforts is whether the lives of women have been improved by them. To address this question, two issues must be considered: how changes in laws and policies enacted pursuant to or independently of constitutional guarantees can be evaluated to determine whether they advance equality, and whether these guarantees of equality are enforced.

The existence of constitutional guarantees of equality and the degree to which they are enforced depends on several factors, including historical circumstance, political sophistication of women, and most importantly, political will. No constitutional guarantee is effective unless the citizens and the leadership of a country determine that enforcement is a priority and commit personal and governmental resources to fulfilling constitutional promises.

The constitutional experience in several Commonwealth countries ${ }^{2}$ illustrates this point. The history of women's rights under the constitutions of Commonwealth African and Caribbean countries that gained independence since 1960, and of Canada, whose constitutional Charter of Rights and Freedoms came into force in 1982, suggests that a guarantee of equality alone will not significantly alter the status of women in any country. The legislature, the executive, and the citizenry, individually and through organizations, all play important roles in developing the political will to make significant changes. In the common law countries the judiciary also plays a significant role in advancing or impeding equality. ${ }^{3}$

To evaluate the effectiveness of a constitutional guarantee of equality, we must examine not only the wording of the document but the laws

2 Commonwealth countries were selected for comparison for two reasons. First, the shared common law legal heritage provides a context for comparison of legislative and judicial activity in different countries in light of shared principles concerning the roles of the legislature and the judiciary, judicial interpretation, and precedent. Second, the variety of forms and levels of economic and political development within the Commonwealth has given rise to various equality issues against a common legal background.

3 The role of the judiciary in interpreting the constitution varies somewhat among the countries discussed in this article. The constitution is supreme to legislation in Kenya (Kenya Const, Ch 1, § 3), Zimbabwe (Zimb Const, Ch 1, § 3) and Jamaica (Jamaica Const, Ch 1, § 2) The situation is somewhat different in Tanzania (see notes 62-67 and accompanying text). Even where the constitution is supreme, the role of the judiciary may be limited by economic and political factors. See, for example, Steven B. Pfeiffer, Notes on the Role of the Judiciary in the Constitutional Systems of East Africa Since Independence, 10 Case W Res J Intl L 12 (1978)(discussing the court systems of Kenya, Tanzania and Uganda). See also notes 40 (Kenya), 86 (Zimbabwe), 103 (Jamaica), and 113 (Canada). Moreover, even the wealthiest individuals in an extremely poor country may have difficulty marshalling the financial resources to pursue an appeal, and legal aid services are scarce. Interview with Virginia Wambui Otieno (Minneapolis, May 10,1988). This is a particular problem in family matters, because the aggrieved parties tend to be divorced women, who, both because of general economic status and (in a fine circularity) as a result of the economic consequences of divorce, are less likely than their former husbands to have the resources for an appeal. See Chuma Himonga, Property Disputes in Law and Practice: Dissolution of Marriage in Zambia, in Alice Armstrong \& Welshman Ncube, eds, Women and Law in Southern Africa 56, 61 (Zimb Pub House, 1987). 
enacted under it and the lives of women living under those laws. Because constitutional guarantees are broad, their effect can only be fully understood by use of a measure that integrates concepts of legal, economic, social, and political status.

\section{MeASURING Equality}

A comprehensive measure of equality rests on the theory of legal capacity. The term "capacity" has a specific, gender-neutral meaning: the ability to undertake enforceable legal obligations and to enforce one's legal rights without aid of a guardian. ${ }^{4}$ The essence of the concept is adulthood, usually measured by age. Many countries provide a statutory age of majority, the age of legal adulthood. ${ }^{5}$

In many countries and cultures, women still have not achieved full legal capacity. They remain legal minors, subject to the authority of a father, husband, or other male guardian all their lives. In sub-Saharan Africa, where customary law applies to most aspects of African citizens' lives, women in some countries cannot inherit land or sign a promissory note for a debt. ${ }^{6}$ Under the provisions of Roman-Dutch common law, applicable to the non-African population in some countries of southern Africa, married women cannot be legal guardians of their own children. ${ }^{7}$

Because it so broadly connotes adulthood, the concept of capacity can be extended beyond its classic de jure meaning to serve as a basic measure of equality. Capacity in its more general sense refers to the ability to accept and to exercise the rights and responsibilities of an adult in one's society. This concept implies both personal commitment to adult responsibilities and the perception of others that one is capable of living up to them. Ultimately, it implies a full range of choice in one's personal,

\footnotetext{
4 The concept of legal capacity rests on the view that "minors [are] not possessed of sufficient discretion to justify holding them liable on their contracts or other obligations. The law assume[s] that minors [will] fall victim to the wiles of designing adults who [will] attempt to take advantage of their inexperience." Susan E. Atchison, Capacity, Parental Power, and a Minor's Right to Remain Married, 22 Santa Clara L Rev 447, 458 (1982).

5 In some societies, adulthood may be defined by rites of passage dictated by religious or customary law. See, for example, Barthazar A. Rwezaura, Traditional Family Law and Change in Tanzania 52-54 (Nomos, 1985) (upon circumcision, Kuria males assume some of the responsibilities of adulthood, enabling their fathers to establish their own homesteads). Such rites correspond only tenuously to the concept of statutorily defined adulthood; recognition of adulthood in customary social systems may be attained only after a series of educational and initiatory events over a period of years. In many countries, a statutory age of majority coexists with such culturally defined processes of attaining adulthood. See notes 58, 91-95, and accompanying text.

6 See Simon Coldham, The Kenya Law of Succession Act, 10 East African L J 93, 99-100 (1974); Joan May, Zimbabwean Women in Customary and Colonial Law, 89-93 (Mambo, 1983); Jane Kikopa, Law and the Status of Women in Tanzania 51-52, UN Doc No E/CN.14/ATRCW Res. 81.04 (1981).

7 Athaliah Molokomme, Marriage-What Every Woman Wants or "Civil Death'?: The Status of Married Women in Botswana, in Women and Law in Southern Africa 181, 184 (cited in note 3).
} 
social, and economic life. ${ }^{8}$

This more general concept of capacity sometimes is recognized in law. Laws that acknowledge women's productive roles in the economy, such as legislation mandating equal treatment in higher education, can be said to recognize implicitly women's adult capacity. Laws that allow unequal treatment, such as failure to allow married women to collect government pensions on the same basis as their husbands or failure to treat homemakers' work as an economic contribution to family property, implicitly deny recognition of women as fully participating members of their society.

A third aspect of capacity is the de facto recognition of women as adults in their daily lives. Even where women have been emancipated by law-both in the classic sense of juridical personality and in the broader sense of legal recognition of adult roles-they may not be acknowledged on a daily basis as fully adult. Once they have reached a legal age of majority, women may have the right to inherit, administer, and dispose of property, to undertake contracts, and to appear in court proceedings on their own. They may have the benefit of married women's property acts, which allow them to maintain their property after marriage and to undertake commercial transactions. Their productive capacity may be acknowledged in the existence of labor laws or state policies concerning equal employment opportunity. ${ }^{9}$ Tradition may dictate, however, that women do not go into business on their own, ${ }^{10}$ that their husbands must be consulted before they enter a contract, or that they cannot obtain contraceptives without a husband's consent. ${ }^{11}$ They may not be perceived as fully responsible adults by their culture-and sometimes by themselveseven though they have legal rights more or less equal to those of men.

The language of capacity allows for discussion of equality issues in the context of positive recognition of ability, role, and value. It focuses on norms of action and inclusion rather than on whether and how women have been excluded. Use of terms such as capacity, ability, and

8 The element of choice is essential to the use of capacity as a measure of equality. Traditionally, in both industrialized and developing countries, women have been assigned a role that is termed "adult," but excludes many activities that male adults have the opportunity to undertake. To paraphrase George Orwell, some are more adult than others. Child-rearing, care of the home, and subsistence economic activities-women's responsibilities-traditionally are part of an adult role, but other undertakings such as wage labor, family decisionmaking, higher education, or participation in public or political life, may be reserved to men. The principle of recognition of equal adult capacity does not devalue the traditional responsibilities of adult women; rather, it adds value to them and opens to women choices hitherto reserved for men.

9 See, for example, The Jamaican Maternity Leave Act (1979) and Employment (Equal Pay for Men and Women) Act (1975); Canadian Employment Equity Act, Stat Can, Ch 31 (1986).

10 The U.S. Equal Credit Opportunity Act, for example, guarantees equality to women only in consumer credit transactions. It allows for exemptions in the granting of business credit. 15 USC $\S 1691$ et seq (West, 1989); 12 CFR $\S 202.3(d), 202.5(d)(1)$ (1989).

11 Rebecca Cook \& Deborah Maine, Spousal Veto Over Family Planning Services, 77 Am J Pub Health 339 (1987). 
participation can expand the equality framework without using the negative term "discrimination."12 While "discrimination," when used with reference to women, may usefully describe a history of exclusion that must be remedied, it also suggests that the exclusion is from an inherently desirable male-oriented and male-defined world. The goal of equality is broader and more humane: women must be recognized and their activities valued in terms of their contributions and abilities. They must have the opportunity to participate effectively in society on terms of equality between women and men that are meaningful in the context of their lives. ${ }^{13}$

In post-industrial societies the concept of capacity applies to ever more complex issues. Even where women have been entering the professions in record numbers and making significant political gains, they have remained subject to stereotypical thinking about their abilities and their interests. ${ }^{14}$ Girls have been tracked away from education in the technical professions, both because they are not expected to have the intellectual capacity to deal with scientific or technical subjects and because they are perceived and educated to be helpmates instead of breadwinners. ${ }^{15}$ Women have been seen as less responsible, not quite grown up, in dealing with money or business. Frequently, because of unspoken apprehensions and lack of training for professional and financial responsibilities, they doubt their own capacity. ${ }^{16}$

In every culture women's paid and unpaid labor is undervalued or not valued at all. Goods and services produced by people who are deemed to be only marginal participants in adult society are not valued

12 Dr. Eddah Gachukia of Kenya, discussing an Expert Group Meeting concerning reporting under the Convention on the Elimination of All Forms of Discrimination Against Women, noted that African women prefer not to use the term "discrimination" because of its connotations in the historical context of colonial race relations. Address by Dr. E. Gachukia, Third Annual Intl Women's Rights Action Watch Seminar (New York, Feb 16 1988).

13 The vision of equality is not just one of access to male-dominated positions, which traditionally is an issue of equality of opportunity, or even of equal treatment in specific contexts. See, for example, N. Colleen Sheppard, Equality, Ideology, and Oppression: Women and the Canadian Charter of Rights and Freedoms, 10 Dalhousie L J 195, 212-15 (1986); Mary Eberts, The Equality Provisions of the Canadian Charter of Rights and Freedoms and Government Institutions, in Clare Beckton \& A. Wayne MacKay, eds, The Courts and the Charter 133, 170-72 (U of Toronto Press, 1986). The Equal Access model implies that equality will be achieved by allowing women to become equal to men by being admitted to male realms and enjoying perquisites traditionally reserved for men. While this is a significant goal, it is limited by a maledefined scale of values. In contrast, recognition of equal adult capacity provides for equality between women and men in that women's work and their abilities are valued on a scale of intrinsic worth rather than on a scale dictated by a male-oriented market, and women's activities in and outside of the workplace are acknowledged as responsible adult activities. See, Note, Toward a Redefinition of Sexual Equality, 95 Harv L Rev 487, 507 (1981) (in order to achieve equality, "it may ultimately be more important to break the links between maleness and importance and between femaleness and triviality" than to press for entry into maledominated domains).

14 Deborah L. Rhode, Justice and Gender 161-75 (Harv U Press, 1989).

15 Lenore J. Weitzman, Sex-Role Socialization in Jo Freeman, ed, Women: A Feminist Perspective 153 (Mayfield, 1979).

16 Id at 191, 201. 
as highly as those produced by people who are seen as fully responsible adults. The classic explanation for the lack of valuation of women's unpaid labor is that standard economic measures relate only to cash transactions, so that, for example, African women's farm labor, which feeds entire nations, is not included in gross national product statistics because it is not exchanged for money. A more basic explanation is that women's work is "invisible"17 not only because it does not always produce cash, but because women's very existence as adults is not fully acknowledged. Thus, in every culture, women's unpaid contribution to the value of marital property is consistently ignored or undervalued, both during marriage and upon divorce. The value of women's agricultural labor is also consistently discounted. ${ }^{18}$

The valuation of women's paid work reflects cultural attitudes concerning women's adult capacity to contribute to the cash economy. Equal pay legislation is an acknowledgement of women's role as adult participants in the paid work force. Comparable worth, a system by which work is valued on the basis of skills and responsibilities required for the job rather than on the basis of job categories that traditionally have been gender-segregated, further recognizes women's capacity by acknowledging the value of work apart from traditional gender identification. ${ }^{19}$ The full value of women's labor inside and outside the home can be recognized only in a context in which there is no "men's work" and "women's work," but only adult work-the work that people do to develop, maintain, and regenerate their society, including agriculture,

17 See Roberta B. Hollander, Out of Tradition: The Position of Women in Kenya and Tanzania During the Pre-Colonial, Colonial, and Post-Independence Eras 317-18 (unpub doc dissert, Am Univ, 1979).

18 The role of women in rural economies frequently is ignored in planning development projects. See Katarina Tomasevski, Women in Development Co-operation: A Human Rights Perspective 10, 11 (unpub manuscript, 1988, avail from Intl Women's Rights Action Watch) (noting the invisibility of women rice processors in Bangladesh whose displacement by an electrified mill was not considered in development plans); Edda Ivan-Smith, Nidhi Tandon \& Jane Connors, Women in Sub-Saharan Africa 7-8 (The Minority Rights Group, 1988) (describing a rice growing scheme in the Gambia that gave land, credit, and market access to men in return for turning in the family plots that women had cultivated for subsistence; the net result was the necessity of importing rice for local consumption, because the men grew cash-crop rice and the women were displaced to inferior plots where they could not grow enough to feed their families); Sara H. Longwe, Report of the African Women's Development Network Workshop (Intl Women's Rights Action Watch, April 1988) (analyzing women's participation levels in development and suggesting new models).

19 The process of measuring skills used in a particular job in order to develop pay scales based on skills rather than job titles is designed to remedy the devaluation of women's and minorities' labor and eventually reach a goal of pay equity: proponents "locate the problem [of differential pay for male- and female-dominated jobs] in the dramatic segregation of the modern labor force by sex and race, and in the consistent devaluation of work associated with women and minorities." Sara Evans \& Barbara J. Nelson, Wage Justice: Comparable Worth and the Paradox of Technocratic Reform 9 (U of Chi Press, 1989). See also Sara Evans \& Barbara J. Nelson, The Impact of Pay Equity in Public Enterprises: State of Minnesota Employee's Attitudes Towards Wage Policy Innovation, in Robert T. Michael \& Heidi I. Hartmann, eds, Pay Equity: Empirical Inquiries 200 (Natl Acad Press, 1989). 
service-sector employment, industrial production, household maintenance, and child rearing.

The status of women within the family and upon dissolution of marriage reflects and determines the position of women in society. Where women have no legal or social personhood outside of their status as wives and mothers, their contribution to their country's economy is invisible, ${ }^{20}$ and their economic contribution to the family is discounted as an indivisible part of their role within the family ${ }^{21}$ rather than as participation in an adult partnership. Decisionmaking capabilities that define adult status in society-opening a bank account, taking a job, traveling, obtaining medical care or education for oneself or one's children-are limited when women's decisionmaking capabilities are not recognized within the family. This is true regardless of the legal regime or the cultural imperatives with which women live.

In every culture and every context, equality can be measured against a conceptual continuum of capacity-from the classic principles of legal capacity to the practical issues concerning the way women are perceived by men and by themselves. While statistical parity with men and equality of opportunity are elements of this measure, respect for the work women do and for the choices they make is as meaningful as employment or literacy profiles.

Constitutional, statutory, and policy changes made in pursuit of equality must have at least the potential of increasing women's adult capacity. In measuring the effectiveness of such changes and in determining the status of women, the single most important question to ask is: to what extent do women and men see women as fully responsible adults in their society?

\section{Women, Constitutions, and Equality}

It is a measure of women's status that even in the late twentieth century they have had only mixed success in entrenching protection of their interests in national constitutions. Some relatively new constitutions lack specific guarantees of sexual equality or nondiscrimination. Of the countries discussed here, Canada has responded the most directly to the interests of its female citizens in preparing its new constitution-and only after considerable effort by women.

Even where they exist, constitutional guarantees in themselves do not create equality. They only create a standard against which laws and

20 See note 18 .

21 See Himonga, Property Disputes, in Women and Law in Southern Africa at 61 (cited in note 3). May, Zimbabwean Women at 75 (cited in note 6) (describing an educated wife's undertaking to support the household financially despite the fact that her husband was a successful businessman, "accepting, as is common among women, her traditional role as provider of domestic necessities"). 
the treatment of citizens by their government can be measured. If laws that discriminate, either on their face or in effect, are not challenged, if nondiscriminatory laws are not enacted, if governments treat their citizens unequally or allow them to be treated unequally by other citizens, inequality will remain despite any constitutional guarantee. Conversely, governments and societies, by changing their laws and policies, may act to remedy inequities despite the lack of a constitutional mandate to do so.

Countries that have ratified the Convention on the Elimination of All Forms of Discrimination Against Women (the Convention) ${ }^{22}$ have a special incentive to provide constitutional guarantees of equality for women and to implement those guarantees in legislation. ${ }^{23}$ The Convention requires, in Article 2, that ratifying countries (States parties) change policies, laws, and constitutional provisions as necessary in order to eliminate

22 UNGA Res 34-180, 34 UN GAOR Supp (No 46) at 193, UN DOC A/34/46 (1979) (entered into force 3 Sept 1981). As of January 1990, 101 countries had ratified the Convention.

23 Id, Arts 17, 18. In many countries, ratification of the Convention will have no direct effect on domestic law unless implementing legislation is enacted. This is true of some Code countries such as Colombia, Maria Isabel Plata, address at the Third Annual Intl Women's Rights Action Watch Seminar (New York, Feb 16, 1988), as well as of most common law jurisdictions. See M. Sornarajah, Bills of Rights: the Commonwealth Debate, 9 Comp \& Intl L J of Southern Africa 161, 167-68 (1976); Chairman's Concluding Statement ("Bangalore Principles"), in Developing Human Rights Jurisprudence: The Domestic Application of International Human Rights Norms ix-x (Proceedings of the Judicial Colloquium in Bangalore, 24-26 Feb 1988) (available from the Commonwealth Secretariat, London). According to the Bangalore Principles issued by the Colloquium, even where implementing legislation has not been enacted, States parties to international human rights treaties can and should be reminded of their treaty obligations by domestic courts, which have an obligation to point out inconsistencies between national law and provisions of international treaties to which the country is a party.

Several international human rights documents in addition to the Convention include provisions concerning women's human rights. The Universal Declaration of Human Rights, adopted and proclaimed, UNGA Res 217A (III) of 10 Dec 1948, states in Article 2 that "everyone is entitled to all the rights and freedoms set forth in this Declaration, without distinction of any kind, such as . . . sex." The International Covenant on Civil and Political Rights, GAOR 2200A (XXI), 999 UNTS 171 (1966) (entered into force 23 March 1976), ratified by all the countries discussed here except Zimbabwe, also states that all the rights in the Covenant shall be recognized without regard to, inter alia, sex (Art 2(1)) and provides for liberty of movement and freedom to choose residence (Art 12), equality before the courts (Art 14), recognition as a person before the law (Art 16) and for free and full consent to marriage with equal rights and responsibilities of spouses as to marriage, during marriage, and at its dissolution (Art 23). The International Covenant on Economic, Social, and Cultural Rights, GAOR 2200A (XXI); 993 UNTS 3 (1966) (entered into force 3 Jan 1976), also ratified by all of the countries discussed here except Zimbabwe, provides for equal human rights of women and men (Art 3), the right to the enjoyment of fair conditions of work (Art 7), equal pay for work of equal value (Art 7), and free consent of spouses to marriage (Art 10). Other treaties providing for women's human rights include the Convention on the Political Rights of Women, GAOR 640 (VII), 193 UNTS 135 (1953) (entered into force 7 July 1954), ratified by Canada, Jamaica and Tanzania, and the Convention on the Nationality of Married Women, GAOR 1040 (XI), 309 UNTS 65 (entered into force 11 Aug 1958). The Convention on the Elimination of All Forms of Discrimination Against Women is the most comprehensive international instrument concerning women's human rights, and 101 countries have ratified or acceded to the Convention as of Jan 1990. Andrew C. Byrnes, The "Other" Human Rights Treaty Body: The Work of the Committee on the Elimination of Discrimination Against Women, 14 Yale J Intl L 1, 4 (1989); Status Report on the Convention on the Elimination of All Forms of Discrimination Against Women (Intl Women's Rights Action Watch, Jan 1990). 
discrimination against their female citizens. Article 15, on legal capacity, states the fundamental premise that women should have full legal capacity, the right to participate as adults in their society with regard to legal obligations, access to the courts, and the right to make decisions on where to live. The other 15 substantive articles of the Convention provide a blueprint for legal and attitudinal change, with a unifying theme of treatment of women as fully adult participants in their society. ${ }^{24}$

States parties to the Convention must report on the status of women and on progress towards equality within one year after ratifying the Convention and every four years thereafter. The reports must be submitted to the United Nations for review by the Committee on the Elimination of Discrimination Against Women (CEDAW), a 23 member body of experts elected by the States parties to the Convention. The reporting obligation, the effect of world opinion, and pressure from women within the country to report and to make changes according to the principles of the Convention may have a positive effect on the quality and quantity of governmental action to effectuate a more equal society.

The drive for equality takes different roads in different countries. In Commonwealth Africa, the Caribbean, and Canada, the context of inequality remains the same-a general attitude that men are the only fully adult persons in the population. But depending on the terms of local history and culture, the strategies for change will vary and are variously successful.

\section{The African Experience}

Kenya, Tanzania, and Zimbabwe share a British colonial heritage and a tradition of multiple or pluralistic legal systems. Under colonial rule, trial and appellate courts heard cases involving persons who were not "natives" (indigenous ethnic groups), applying the "received" or "general" law which consisted of common law principles and statutes in force in England or other colonies at a particular date. ${ }^{25}$ Matters concerning Africans (indigenous peoples) were taken before local courts that applied the customary law ${ }^{26}$ of the parties. Frequently a third hierarchy

24 Other substantive articles of the Convention define discrimination (Art 1) and require States parties to take all appropriate measures to eliminate discrimination in political and public life (Art 7), nationality provisions (Art 9), education (Art 10), employment (Art 11), and health care and family planning (Art 12). Article 4 allows parties to take temporary special measures to meet the objectives of equality. Article 14 specifically addresses the circumstances of rural women. Article 16 provides for equality in the family-upon marriage, during marriage, and at dissolution of marriage.

25 For example, the received law in Zimbabwe is "the law in force in the colony of the Cape of Good Hope on 10th June, 1891, as modified by subsequent legislation having in Zimbabwe the force of law." Zimbabwe Const, $\S 89$.

26 "Customary law" is a term used to describe a set of unwritten rules by which communities regulate their members" behavior. The rules are "generated by a community's acceptance of certain standards of behavior" rather than by legislation or court decree. They are ascertained 
of tribunals also coexisted with the first two, "staffed mainly by White administrative officers and designed to reflect a blend between the tribal courts and the White courts."27 Upon independence, efforts were made to unify the court systems and to eliminate racial criteria for jurisdiction. ${ }^{28}$ Multiple legal systems remain in effect, however, in that all courts in the system apply customary law, as modified by subsequent statutory enactments, in personal and family matters (divorce, child custody, maintenance, inheritance) ${ }^{29}$ where the parties are members of an ethnic group that has its own customary law.

The pluralistic legal tradition has a special effect on women, since customary law does not provide women the rights of adult capacity provided by statutory systems. Unless its applicability is altered by statute, customary law is applied in most legal circumstances involving African women. ${ }^{30}$ Traditionally, women governed by customary law are perpetual legal minors, ${ }^{31}$ living their entire lives under the authority of a male

by observation or consultation. Because they are applied situationally they may appear unsystematic as compared with the standards used by western lawyers. See T. W. Bennett, Application of Customary Law in Southern Africa 17-18 (Juta, 1975). As discussed in notes 30-38 and accompanying text, customary law in Africa today is invoked in circumstances of personal life: marriage, divorce, child custody, death, and inheritance. Customary law is different from religious law, which generally is based on written text or revelation and frequently relies as well on a scholarly tradition of interpretation. Religion and custom intermingle in Africa in a variety of ways: some ethnic groups are identified with a particular religion, such as the Muslim Hausa of Nigeria; some people profess a religion and follow its tenets but incorporate customary practices into their lives to the extent that the customs do not conflict with Christian or Muslim doctrine; some have abandoned all forms of customary practice; many are animists, whose spiritual life is closely identified with customary practices.

27 An excellent overview of the history and development of the pluralistic legal system with respect to marriage laws in particular is found in T.W. Bennett \& N. S. Peart, The Dualism of Marriage Laws in Africa, 1983 Acta Juridica 145, 145-49. See also Akilagpa Sawyerr, Application of Law in Tanzania: A "Proper Remedy" Approach to Some Problems of Legal Pluralism, 6 Eastern Africa L Rev 265 (1973) (organization of the courts in post-independence Tanzania).

28 Bennett \& Peart, The Dualism of Marriage Laws at 147 (cited in note 27).

29 Africa is not unique in retaining religious or customary law as to family and personal matters while governing other legal relations under a unified system of statutory and judicially developed case law. This system is common in many countries in Asia and exists as well in such industrialized countries as Israel. The persistence of the plural system in Africa has been attributed to political factors and to the difficulty of drafting a politically acceptable personal law code that will allow for diverse practices within a unified system. See id. The reluctance or inability of the state to deal with the question of personal law also evidences a strong bias towards maintaining male prerogatives, as most unification schemes or suggested changes in religious or customary practices, which primarily affect family, inheritance, and property law, result in new rights for women. See, for example, id at 148-49; see also Otieno v Ougo, Kenya Court of Appeal, May 15, 1987 (unoffic pub in The Weekly Review (Nairobi) 11 (May 22, 1987)); John W. Van Doren, Death African Style: The Case of S. M. Otieno, 36 Am J Comp L 329, 343 (1988).

30 See generally Otieno v Ougo (cited in note 29); Van Doren, Death African Style at 331 (cited in note 29).

31 As an invention of modern western legal systems, the term "legal minor" has limited applicability in the context of pre-colonial African cultures. Prior to the imposition of western legal concepts, adult roles and responsibilities were assigned-or earned-according to age group as well as gender. See May, Zimbabwean Women at 22-23 (cited in note 6); Rwezaura, Traditional Family Law at 11-15, 29-31, 53 (cited in note 5). As the colonial economic and legal systems were superimposed on local cultures, and men began to pay tax as householders and to work for wages, the idea of a legal "major" who could contract for employment or govern- 
guardian-father, husband, brother, or uncle. ${ }^{32}$ Generally speaking, under customary law women do not have the right to own, inherit, or manage property. ${ }^{33}$ When they divorce, they have no rights to property, post-divorce financial support, or custody of their children. ${ }^{34}$

The legal position of European (white) women, who are subject to the received law, historically has been somewhat better. They become full legal adults upon reaching age of majority as defined by the received law. Under received English or other colonial married women's property acts, still current in many countries, women can own and manage property even after marriage, and under divorce statutes they have some rights to property and custody of children upon dissolution of marriage. ${ }^{35}$

African women may be subject to customary law in their family relations even if they marry by Christian rite or civil registry. ${ }^{36}$ Changes in their status, and in their rights, may be made only by statute, and the changes will be limited to the rights specifically addressed in the statute. For example, when Virginia Wambui Otieno wanted to bury her late husband at their farm near Nairobi, and her husband's clan fought to bury him on family land in western Kenya according to Luo custom, the Kenya Court of Appeal granted the burial rights to the Luo clan on the ground, inter alia, that those rights belonged to the clan according to customary law and no existing statute altered the custom. ${ }^{37}$ In contrast,

ment services was applied to the local adult male population and eventually extended into all areas of life. The issue of legal majority, or contractual capacity, did not arise as to women, because they were excluded from the cash economy and thus were invisible to colonial governments. This distinction between men and women as to achievement of majority continues to hold in many African countries. Conversation with Prof. B. A. Rwezaura (Feb 1988).

32 See Weiss, Women of Zimbabwe at $111-13$ (cited in note 1); Rwezaura, Traditional Family Law at 79 (cited in note 5).

33 See, for example, Himonga, Property Disputes, in Women and Law in Southern Africa at 68-69 (cited in note 3); May, Zimbabwean Women at 89 (cited in note 6).

34 Welshman Ncube, Underprivilege and Inequality: The Matrimonial Property Rights of Women in Zimbabwe, in Women and Law in Southern Africa 1, 11 (cited in note 3); The Rejection of the Marriage Bill in Kenya, $23 \mathrm{~J}$ of African Law 109, 113 (1979); Barthazar A. Rwezaura, Towards a Fair Concept of Individual and Family Assets (paper presented at the Eighth Commonwealth Law Conference, Jamaica, 1986); Himonga, Property Disputes, in Women and Law in Southern Africa at 56-61 (cited in note 3).

35 For example, in Kenya, dissolution of a marriage contracted under the Marriage Act, which governs marriages between Europeans, is governed by the Matrimonial Causes Act, Ch 152, which offers the possibility of property division and post-divorce maintenance. Those individuals married according to the customary law of indigenous ethnic groups must divorce by customary law, under which women generally have no rights to maintenance, child support, or property division.

36 See Mwangi and Others v West, 1976 Kenya L Rep 203, 208; Julie Stewart, Playing the Game: Women's Inheritance of Property in Zimbabwe, in Women and Law in Southern Africa 85, 87 88 (cited in note 3 ).

37 The case of Otieno v Ougo, cited in note 29, arose when S. M. Otieno, a prominent Nairobi attorney who was born into a Luo clan, died intestate. When S. M. married Virginia Wambui Otieno, a Kikuyu, in 1961, the couple made headlines because marriages between members of different ethnic groups in Kenya were very rare. The couple lived in Nairobi. Wambui had been active in the uprising leading to independence and was prominent in the women's movement in Kenya. The couple belonged to a Christian church. Their children spoke Swahili and 
while customary law makes no provision for a widow to inherit or administer property because traditionally the extended family was expected to provide for her, the Kenya Law of Succession Act, enacted in 1972 , allows a widow to inherit an interest in her husband's property and to administer his estate. ${ }^{38}$

Legal change in Commonwealth Africa has been both a response to changing social conditions and an attempt at social engineering. With urbanization and the growth of women's participation in the wage economy, social and economic support through the rural-based extended family, on which the premises of customary law rest, has eroded, and new legal rights that reflect new realities are necessary. ${ }^{39}$ Practical application of legal rights is problematic because women must assert them in the face of traditional male attitudes that deny women's full adulthood. Without the legal rights, however, women could not hope for equal treatment as responsible adults.

\section{The Equality Effort in Kenya}

The history of the Kenya Law of Succession Act illustrates the premise that constitutional guarantees may have little to do with achievement of rights for women and that, conversely, political will may result in new legislation where the constitution fails to grant women the right to be free from sex-based discrimination.

The Kenyan Constitution reflects its British sponsorship and the British legal heritage. ${ }^{40}$ It guarantees a set of "fundamental rights and freedoms": the right to "life, liberty, security of the person and the protection of the law"; "freedom of conscience, of expression and of assem-

English, but not the languages of either ethnic group. When S. M. died, his brother claimed that S. M. must be buried according to the ritual of the Luo, in western Kenya. Wambui claimed that S. M. had expressed a wish to be buried on their farm in Nairobi. She argued that the Kenya Law of Succession Act, which gave widows the right to administer their deceased husbands' property, gave her the right to dispose of his remains. S. M.'s clan argued that the Law of Succession Act did not apply to the issue of burial and that in the absence of any applicable statute, customary law must apply to burial rituals. The clan prevailed after six months of bitter legal argument and elaborate press coverage. In a decision that contrasted dramatically with the attitude demonstrated by the Zimbabwe Supreme Court in interpreting Zimbabwe's Legal Age of Majority Act (see notes 93-95 and accompanying text), the Kenya Court of Appeal interpreted the Law of Succession Act narrowly and held that the right to administer the estate did not extend to burial rights. See generally Van Doren, Death African Style (cited in note 29), and notes $51-52$ and accompanying text.

38 Kenya Law of Succession Act, $\S \S 35,36,37,66$ (1972).

39 See Himonga, Property Disputes, in Women and Law in Southern Africa at 60-61 (cited in note 3).

40 The Kenyan Constitution, like that of Zimbabwe and Jamaica, initially was a product of negotiation with representatives of the Crown at the time of independence. This "Westminster Model" established a parliamentary government with an independent judiciary. For a variety of political and historical reasons, this model also includes a Bill of Rights that, inter alia, prohibits discrimination. See Y. P. Ghai, Constitutions and the Political Order in East Africa, 21 Intl \& Comp L Q 403, 412-17 (1972); E. J. M. Zvobgo, The Zimbabwe Constitution After Four Years of Independence, 1984 Pub L 447, 447-48. 
bly and association"; protection of the privacy of home and property; and protection of property from governmental taking without compensation. All of these protections are granted regardless of "race, tribe, place of origin, or residence or other local connection, political opinion, colour, creed, or sex." 41

The Constitution also includes a nondiscrimination provision: "no law shall make any provision that is discriminatory either of itself or in its effect. ... [No] person shall be treated in a discriminatory manner by a person acting by virtue of any written law or in the performance of the functions of a public office or a public authority."42 However, this provision applies to discrimination on the basis of "race, place of origin, political opinions, colour or creed"43-not sex. The most significant limitation on this constitutional guarantee of nondiscrimination is that it does not extend to those areas of law and policy in which women's legal disadvantages are the greatest: "adoption, marriage, divorce, burial, devolution of property on death or other matters of personal law."44

These provisions, which are found in many Commonwealth constitutions, reflect the essential invisibility of women in the constitutional process. "Fundamental freedoms"-freedom of expression, of assembly, of property ownership - may be meaningless to people who are excluded by tradition from public life and property ownership. Even if the nondiscrimination provision were extended to prohibit discrimination on the basis of sex, the exclusion of personal and family matters from its ambit would render it meaningless for most women, because discrimination against women in matters of inheritance, custody, marriage, and divorce would remain constitutionally permissible. ${ }^{45}$ If a woman legally can be deprived of rights to own or dispose of marital or inherited property, or can be deprived of custody of her children solely because she is a woman, then her culture is very far indeed from seeing her as an adult capable of carrying adult responsibilities.

Although the Constitution fails to acknowledge meaningfully women's adult capacity, the Kenyan government has, over the 25 years since independence, displayed considerable will to give women some of the legal rights and the recognition necessary to their participation as adults in their society. In 1967 President Kenyatta appointed commissions on the Law of Marriage and Divorce and on the Law of Succession. The commissions were charged with evaluating the state of the law in their respective areas and suggesting changes that would integrate the

41 Kenya Const, $\S 70$.

42 Id, $\S 82(1,2)$.

43 Id, $\$ 82(3)$.

44 Id, $\$ 82(4)$.

45 Gladys Mutukwa, Implementation of the 1979 United Nations Convention on the Elimination of All Forms of Discrimination Against Women in Africa 38 (available from Intl Women's Rights Action Watch, 1987). 
different legal systems in Kenya in order to create a comprehensive system suitable to a contemporary, unified country. The mandate of the Commission of the Law of Marriage and Divorce specifically included a requirement "to pay particular attention to the status of women in relation to marriage and divorce in a free democratic society."

The recommendations of both commissions, including proposed legislation, were presented in 1968. The Law of Succession Act, which incorporates essentially all of the provisions suggested by the commission, was passed in 1972. Its passage was revolutionary in that the Act provides widows with inheritance rights unheard of in societies governed by customary law and gives men and women equal rights to inherit from a parent or sibling, ${ }^{47}$ thus acknowledging women's capacity to exercise property rights responsibly. At the same time, it bows to tradition by limiting a widow's right to dispose of the property as she sees fit. The Law of Succession Act establishes a scheme in which the surviving spouse essentially holds only a life interest-a form of trust for the children-and provides that a widow's, but not a widower's, interest terminates upon remarriage. ${ }^{48}$

The $\mathbb{L}$ aw of Succession Act was so revolutionary that its effective date was delayed until 1981. Its coming into force generated a good deal of excitement among women, and considerable publicity educated the public about its provisions. ${ }^{49}$ Public interest in the Act was heightened by the case of Otieno $v$ Ougo (1987), ${ }^{50}$ in which the Act's provisions for widows were invoked in support of Mrs. Otieno's claim to burial rights over her husband's body. ${ }^{51}$

The proposed Marriage Act, which gives women a number of new rights, did not fare as well. It continues to languish in Parliament, where

46 Kenya Commission on Law of Marriage and Divorce, Report of the Commission, introductory page (Govt Printer, 1968). See also Eugene Cotran, The Development and Reform of the Law in Kenya, 27 J African L 42, 49 (1983) (the two reports "were undoubtedly slanted in favor of women").

47 Kenya Law of Succession Act, $\S \S 35-39$ (1972). See Coldham, The Kenya Law of Succession Act at 100 (cited in note 6).

48 Kenya Law of Succession Act, $\S \S 35-37$ (1972). See Coldham, The Kenya Law of Succession Act at 100 (cited in note 6).

49 See Mukami Ireri, The Law of Succession Act, 7 Viva 8 (Aug 1981); Mukami Ireri, Understanding the New Law of Succession, 7 Viva 58 (Sept 1981); Why They Said What They Did, Weekly Review (Nairobi) 21 (May 22, 1987).

50 See note 29.

51 The case generated a great deal of local and international publicity. The narrow legal issue on which Mrs. Otieno lost was whether a widow of a contemporary intertribal marriage had a right to bury her husband according to his expressed wishes, which were contrary to his clan's custom. See note 37 above. The broader issues raised in the course of the proceedings-and far from settled now-concerned "the underlying struggle to win real responsibility for herself as a woman in a society that frowns at that." S. M.: Wambui's Defeat Is Defeat for Women, 4 Viva 16, 17 (June 1987). Dr. Eddah Gachukia of Kenya, speaking at the Third Annual International Women's Rights Action Watch Seminar (New York, Feb 16, 1988), remarked that despite Wambui's defeat, the case provided a major vehicle for public education about women's rights under the Law of Succession Act. 
it generated fierce debate upon its last consideration in 1979.52 The proposed Act follows to a great extent the legislation suggested by the Commission on the Law of Marriage and Divorce. The Commission sought to design a workable law that would provide a single legal framework for all marriages, improve the status of women, and preserve important elements of the African way of life. ${ }^{53}$ Because the Commission hesitated to depart from customary norms, its proposals are not as progressive as some women's rights advocates would have liked. ${ }^{54}$ On the other hand, many provisions of the proposed Act would significantly change the real and perceived status of women by expanding their role as responsible adults with decision-making capacity, particularly in relation to their husbands. ${ }^{55}$ It is this implication of the proposed Act that has created difficulties in the almost all-male Parliament. ${ }^{56}$

As an appropriate and necessary complement to the new Law of Succession Act, a new Age of Majority Act was passed in 1974. The law was proposed as a companion to the proposed Law of Marriage and Divorce; the Commission on the Law of Marriage and Divorce stated that "there should be one age of majority for everyone, regardless of sex or race." 57 The new Age of Majority Act provided a uniform age of majority for all Kenyan citizens, regardless of the age at which women had traditionally been regarded as adults by their communities. ${ }^{58}$

Kenya ratified the Convention on the Elimination of All Forms of Discrimination in 1984. The ratification seems to have had little effect on the fate of the proposed Marriage Act, but other developments suggest that the role of women remains on the national agenda. The Kenyan government devoted considerable resources to hosting the 1985 world conference marking the end of the International Decade for Women, and 14,000 women attended the Nongovernmental Forum held in conjunction with the conference. Recently a group of women who had been involved in the Nairobi conference established the African Women's Development and Communication Network (FEMNET), an organiza-

52 Rejection of the Marriage Bill (cited in note 34); Should We Be "Modern" or Traditional?, Weekly Review (Nairobi) 28 (May 22, 1987).

53 Report of the Commission at 2-3 (cited in note 46).

54 See Barbara H. Mitchell, Improving the Status of Women Through Family Law Reform: The Tanzanian Experience, 8 Melanesian L J 54 (1980).

55 The proposed Marriage Act would have prohibited marriages without the consent of the parties $(\S 24)$, prohibited the taking of a second or subsequent wife if a current wife objects $(\S 28)$, given women a right to part of the couple's property upon divorce $(\$ 114)$, and recognized a woman's ability to undertake the responsibility of providing for children (by applying a "welfare of the children" standard as well as custom) (\$ 128). The Marriage Bill (Kenya, 1979).

56 See Hilary Ng'weno, Letter from the Editor, Weekly Review (Nairobi) 1 (Jan 16, 1987); Should We Be "Modern" (cited in note 52).

57 Report of the Commission at 76 (cited in note 46).

58 See Robert Martin, The Age of Majority and the Kenya Law of Succession Act, 1972, 9 East African L J 77, 82-84 (1973). The strategy of invoking the Age of Majority Act to gain legal recognition of women's adult capacity has not been used in Kenya as it has in Zimbabwe. See notes $91-93$ and accompanying text. 
tion headquartered in Nairobi which specifically focuses on the recognition of women's capacity to participate in development. ${ }^{59}$ President Daniel arap Moi announced in January 1986 that he intended to appoint 20 women to responsible (and visible) positions. By June 1987, he had appointed a woman assistant cabinet minister, at least seven women had been appointed to head parastatal organizations, four held ambassadorial posts, and the first woman permanent secretary in a government ministry had been appointed. ${ }^{60}$

While Kenya was the first Commonwealth African country to attempt massive legal change in acknowledgement of women's capacities, the momentum has stalled. The political will to undertake fundamental legal change challenging cultural assumptions has not sustained itself. Despite this, actions by the executive and women's continuing activity to address the issues of women's visible participation in society indicate that women will not be relegated forever to their state of invisibility.

\section{Tanzania: A Marriage Law for the Future}

The enactment of the Law of Marriage Act in Tanzania in 1971 demonstrates the efficacy of political will where the constitution does not provide for equality between the sexes or where the legal and practical meaning of constitutional guarantees has not been established. The Act was modeled on the Kenyan Marriage Act proposed but not passed by the Kenya Parliament. ${ }^{61}$

When the Law of Marriage Act was passed, the 1965 Interim Constitution of Tanzania, which included no guarantees of equality or protections of fundamental freedoms other than a general statement in its preamble, was in effect. ${ }^{62}$ The current Tanzanian Constitution, enacted

59 Longwe, Report of the African Women's Development Network Workshop (cited in note 18).

60 See Year in Review, Weekly Review (Nairobi) 3 (Jan 2, 1987); Margaret Githinji, Weekly Review (Nairobi) 12 (June 5, 1987).

61 Tanzania Law of Marriage Act (1971). The general purpose and structure of the Act and much of its wording are the same as those of the Kenyan Law of Matrimony proposed by the Kenya Commission on the Law of Marriage and Divorce in 1968 and introduced as the Marriage Bill in Kenya in 1979.

62 Much has been written on the significant changes in the Tanzanian Constitution since independence in 1961. In 1964, Tanzania was formed by the union of Tanganyika and Zanzibar, and the Interim Constitution of 1965 was adopted to serve the country as it worked out certain aspects of unification. This Constitution declared the Tanganyika African National Union (TANU) to be the only party in the country, and the TANU constitution was incorporated into the national constitution as a schedule. The national constitution did not include a bill of rights or any reference to nondiscrimination aside from its preamble, which does not have binding effect under common law principles. C. M. Peter, Justice in a One-Party African State: The Tanzanian Experience, A Rejoinder, 20 Verfassung und Recht in Ubersee 235, 250 (1987). The TANU constitution, however, did include some guarantees of fundamental rights which were "enforced" in at least one case. Id at 250-51. The 1977 national constitution did not include either a bill of rights or a party constitution; "[c]ivil liberties were conspicuous by their omission." Umesh Kumar, Justice in a One-Party African State: The Tanzanian Experience, 19 Verfassung und Recht in Ubersee 255, 262 (1986). The Presidential Commission on the Establishment of a One-Party State reported in 1965 that a bill of rights was unnecessary 
in 1984 , includes a provision requiring the government to "offer equal opportunities for all citizens, men and women, regardless of color, tribe, religion, or creed." ${ }^{63}$ Because this clause appears in the section devoted to stated objectives of the government, there may be some argument as to whether it amounts to a guarantee. ${ }^{64}$ Lawyers could differ on whether the term "equal opportunities" applies in the context of personal law, or the extent to which it can apply. The degree of protection afforded by such a broad term can only be defined through a process of constitutional adjudication. ${ }^{65}$

The current Constitution of Tanzania also provides that "it is forbidden for any law enacted by any authority in the Union Republic to impose any condition which is of a discriminatory nature or which is obviously to one's disadvantage."66 It defines "discrimination" as "meeting the needs, rights or other requirements of different people based on their nationality, tribe, their origin, their political affiliation, color, religion or their lifestyles in such a way that certain people are made or considered inferior . . ." Un Unlike the discrimination provision in the Kenyan Constitution, the Tanzanian provision does not explicitly exclude matters of family or personal law from its ambit. However, its usefulness in the context of discrimination against women is limited, because it does not include sex as a prohibited basis of discrimination.

Although the elimination of sex-based discrimination is not required by either the 1965 Interim Constitution or current constitutional provisions, Tanzania's Law of Marriage Act purports to eliminate or modify

and potentially disruptive to the work of developing a contemporary one-party democracy. See Alex H. Amankwah, Constitutions and Bills of Rights in Third World Nations: Issues of Form and Content, 21 Comp \& Intl L J of Southern Africa 190, 208 (1988) (quoting the Commission):

If a Bill of Rights were written into the Constitution, it would have overriding legislative effect. This means that the courts could be asked to declare invalid any laws passed by parliament if it [sic] were inconsistent with a provision contained in the Bill of Rights. By requiring the courts to stand in judgment on the legislature the Commission feels that the judiciary would be drawn into the area of political controversy.

63 Tanz Const, $\S 9(1)(\mathrm{g})$.

64 See Kumar, Justice in a One-Party African State at 272-74 (cited in note 62); Peter, Justice in a One-Party African State, Rejoinder at 249-53 (cited in note 62).

65 The question of constitutional adjudication in a one-party state in which the party is supreme to the government has received considerable scholarly attention. Scholars have raised such issues as the standards of constitutional review and the independence of the judiciary. See Kumar, Justice in a One-Party African State at 265-71 (cited in note 62); C. M. Peter \& M. K. B. Wambali, Independence of the Judiciary in Tanzania: A Critique, 21 Verfassung und Recht in Ubersee 72 (1988); James C. N. Paul, Some Observations on Constitutionalism, Judicial Review, and Rule of Law in Africa, 35 Ohio St L J 851 (1974) (reviewing the reasons for lack of constitutional activism in bench and bar in the first ten years of African independence). To date, while the Court of Appeal has decided several family law cases, the decisions have focused on statutory interpretation rather than constitutional rights. See Peter \& Wambali, Independence of the Judiciary at 86 (cited in this note) (noting the "courage" of the Court of Appeal in Hawa Mohamed v Ally Sefu (Ct of App of Tanz at Dar es Salaam, Civ App No 9 of 1983), in liberally interpreting the property provisions of the Law of Marriage Act).

66 Tanz Const, $\$ 13(2)$.

67 Id, § 13(5). 
some of the most invidious forms of discrimination against women inherent in all the family law systems applicable in the country at the time of independence. Immediately after the report of the Kenya Commission on the Law of Marriage and Divorce was released, the Tanzanian government issued a White Paper suggesting similar changes. ${ }^{68}$ The White Paper referred to the socialist goals stated only two years earlier in the Arusha Declaration. ${ }^{69}$ As one commentator has stated, "The new law was intended to promote respect and equality in the marriage and was therefore consistent with the goals and aspirations of the entire country. [I] $t$ was essential that the law should protect the rights of the wife so that she may bring up her children to be good citizens."

The Tanzanian Law of Marriage Act departs from customary and Islamic marriage law in several significant ways. Although the Act does not prohibit polygyny, the law as proposed in Kenya and enacted in Tanzania gives women in potentially polygynous (customary or Islamic) marriages a veto over their husband's marriage to a new wife. ${ }^{71}$ While the grounds on which a wife can object are somewhat limited, ${ }^{72}$ the very requirement of consultation and the possibility of rejection by the current wife are radical changes in the status of wives with respect to their husbands. The capacity to make decisions about the family structure no longer rests solely with the husband.

The Law of Marriage Act also provides that no marriage may be entered into without the consent of both parties, ${ }^{73}$ a change from the customary marriage tradition in which the families arranged the marriage, and consent of the parties, particularly the women, usually was

68 Government White Paper No 1 of 1969, Tanz (mainland).

69 The Arusha Declaration was issued in 1967 by President Nyerere. It declared the goals of Tanzania as a socialist state. See Pfeiffer, Notes on the Role of the Judiciary at 39 (cited in note 3).

70 Barthazar A. Rwezaura, The Integration of Personal Laws: Tanzania's Experience, 1 \& 2 Zimb L Rev 85, 90 (1983-84). See also Kassam, Comments on the White Paper, 2 Eastern Africa L Rev 329, 337 (1969). Rwezaura, in Traditional Family Law at 88 (cited in note 5), notes the influence of President Nyerere's position on equality between the sexes. Nyerere has consistently stated that equality is essential to the country's progress, and that sexual inequality is inconsistent with socialist ideals. See Barthazar A. Rwezaura, Islamic Divorce in Tanzania: A Study of Tension Between Law in the Books and Living Law, 9 Eastem Africa L Rev 99, 102 (1975).

71 Kenya Marriage Bill, $\S 28$ (1979); Tanzania Law of Marriage Act, $\S \S 20-21$ (1971).

72 The current wife or wives of a man who proposes to take an additional wife may object to the marriage if, given his financial means, taking another wife will result in "hardship to his existing wife or wives and infant children, if any." Law of Marriage Act, § 20(2)(a) (1971). The wife or wives may also object if "the intended wife is of notoriously bad character or is suffering from an infectious or otherwise communicable disease or is likely to introduce grave discord into the household." Id, $\S 20(2)(b)$.

The Kenya Commission did not recommend abolition of polygyny, on the ground that it would be so radical a departure as to be unenforceable and thus detract from the credibility of the entire Act. It also assumed that the practice would die out on its own. Report of the Commission at 22 (cited in note 46). This assumption has proven to be unjustified. According to Rwezaura, Traditional Family Law at 120 (cited in note 5), raw statistics indicate that polygyny increased in certain parts of Tanzania between 1957 and 1967.

73 Law of Marriage Act, $\S 16$ (1971). 
irrelevant. ${ }^{74}$ The provision requiring consent is a significant expansion of women's decisionmaking role regarding their marriages-even if, as skeptics suggest, consent can be coerced. ${ }^{75}$

The divorce and custody provisions of the Law of Marriage Act also mark an expansion of women's adult roles. The customary legal premise that custody of children of a dissolved marriage always goes to the father is replaced by a "best interest of the child" standard, with a presumption that children under the age of seven should live with their mother. ${ }^{76}$ The role of mothers as adults capable of supervising and guiding children is thus acknowledged.

Perhaps the most important change made by the Law of Marriage Act is the grant of full legal capacity to all married women regardless of the means of formalizing the marriage. Wives are granted separate and equal rights to hold and dispose of property, to make contracts, and to sue and be sued in contract or in tort. ${ }^{77}$ Women's unpaid contribution to the value of marital property, unacknowledged in customary law, is recognized upon divorce, in that the wife is granted an interest in the marital home regardless of her financial contribution, ${ }^{78}$ and property acquired by the "joint efforts" of the couple is to be divided between them. ${ }^{79}$

The persistence of women's advocates and the ultimate willingness of the nation's highest court to reexamine its position on the meaning of "joint efforts" have been crucial factors in the practical application of the Law of Marriage Act. For twelve years after enactment of the Law of Marriage Act, the courts required proof of financial contribution in order to give women a share of marital property. In 1983, the Tanzanian Court of Appeal, the highest court, decided that a wife's work in the home must be considered a contribution to the couple's joint efforts. ${ }^{80}$

The social effects of legal change manifest themselves gradually. When the White Paper was under discussion in 1969, letters to the editors of the Dar es Salaam newspapers suggested that some, but far from

74 The question of consent in customary marriage is complex. While customary marriage is an arrangement between families which does not require the couple's consent in order to be valid, in some traditions the couple's wishes may be considered by their parents. See, for example, Michael Gelfand, The Shona Woman, X no 5 NADA 41, 42-44 (1973); Rwezaura, Traditional Family Law at 54-69 (1985) (cited in note 5) (suggesting both that women in pre-colonial days could indicate their interest in accepting a particular man, and that parents exerted a great deal of control over marital choice).

75 Mitchell, Improving the Status of Women at 62 (cited in note 54).

76 Law of Marriage Act, $\$ 125$ (1971). Kikopa notes, however, that since the law also requires the court to refer to the couple's community customs, children are still more likely to go to the father in a custody dispute. Kikopa, Law and Stotus of Women at 49 (cited in note 6).

77 Law of Marriage Act, $\S 56,58$ (1971).

78 Id, $\S 59$.

79 Id, $\$ 114$.

80 Peter \& Wambali, Independence of the Judiciary at 86-87 (cited in note 65); Barthazar Rwezaura \& Ulrike Wanitzek, Family Law Reform and Socio-Economic Developments in Africa: Family Property and the Law in Tanzania, 2 Intl J L \& Family 1, 17 (1988). 
all, members of the educated public were in favor of change. ${ }^{81}$ An investigation of the use of the courts in divorce matters in rural Tanzania a few years after enactment of the Law of Marriage Act suggested that in some areas women were applying to the courts to obtain compensation for their labor as wives, seeing an opportunity to obtain under the Law of Marriage Act a recognition of their economic efforts that they had not been able to obtain under customary law. ${ }^{82}$ However, the research also suggested that many couples were attempting to divorce outside of the court system, contrary to the provisions of the Act, and were only applying to the courts when there was a dispute between husbands and their fathers-in-law concerning the return of bridewealth. They became educated in the legal requirements for divorce by having the bridewealth claims rejected on grounds that a valid judicial divorce must precede the bridewealth claim. ${ }^{83}$

Tanzania ratified the Convention on the Elimination of All Forms of Discrimination Against Women in 1985. While the ratification indicates a continuing commitment to the principles of equality, the Tanzanian report to CEDAW is minimal and does not include any information on the Law of Marriage Act and its effects. ${ }^{84}$ This lapse, coupled with the history of the Law of Marriage Act, suggests that even where political will exists to effect legal change which would provide a framework for change in people's lives, governments must commit to a continuing effort to educate citizens about the change, and citizens must understand and accept the new laws in order for them to have their intended effect.

\section{Zimbabwe: The New Woman}

Women in Zimbabwe have benefited both from political leaders' awareness of women's interests and from women's participation in the civil war in the 1970 s. $^{85}$ The Zimbabwe constitutional provisions concerning sexual equality are almost identical to those of Kenya: they include only a general guarantee of equality as to fundamental freedoms and exclude both women and personal law from the nondiscrimination

81 See Kassam, Comments at 338 (cited in note 70).

82 See Rwezaura, Integration of Personal Laws at 93-94 (cited in note 70). In fact, historically, women were induced to apply to colonial courts in marital matters because they had little hope of fair treatment in the traditional setting in which decisions were made by male elders. Rwezaura, Traditional Family Law at 133-34 (cited in note 5).

83 See Rwezaura, Integration of Personal Laws at $91-92$ (cited in note 70); Rwezaura, Integration of Marriage Laws in Africa with Special Reference to Tanzania at 20-21, presented at the Regional Conference on Social Change and Legal Reform, Harare, Zimbabwe (Jan, 1987).

84 Initial Reports of State Parties: Tanzania, UN Doc No CEDAW C/5/Add 57 (1988).

85 Zimbabwe achieved majority rule after 15 years of civil war, which began after the Ian Smith government unilaterally declared independence from Great Britain under minority (white) rule in 1965. The late stages of the war, 1972-79, were particularly intense. Women served in the war effort, both in the field and in maintaining family and community structures during the disruption. Some became commanders. See Weiss, Women of Zimbabwe at 13-23, 105-11 (cited in note 1) (profiling several women who were active in the war). 
provisions. ${ }^{86}$ Zimbabwe has not ratified the Convention on the Elimination of All Forms of Discrimination Against Women. However, the country has a number of strong women leaders ${ }^{87}$ and changes in the court system made under the Customary Law Act and Primary Courts Act, 1981 , brought women into the judiciary for the first time. ${ }^{88}$

The legal situation of African women in Zimbabwe has not differed significantly from that of other Commonwealth African women. They have been, with few exceptions, subject to limitations of their rights and their roles under customary law systems that treat them as legal minors for their entire lives. ${ }^{89}$ However, in 1982, the status of women was dramatically altered with the passage of the Legal Age of Majority Act. ${ }^{90}$ The terms of the Act are very simple: every person becomes a legal major at the age of eighteen. The Act explicitly states that it applies to cases involving customary law. This implies that women have full legal status equal to that of men, even in transactions in which customary law determines the rights of the parties, such as inheritance and marital property.

The extension of the concept of legal majority to all citizens in all legal contexts is revolutionary in that it constitutes a comprehensive change in the perceived role and capacity of women, and particularly of African women. Women are not to be treated as adults in some situations and as minors in others, as can occur when changes are made in the marriage law but not in the law of inheritance or property ownership.

86 Zimb Const $\$ 11,23$. A negotiated peace and fully recognized independence were achieved in 1979, Weiss, Women of Zimbabwe at 96-97 (cited in note 1), and a new constitution was drawn up based on the Westminster model. Several changes have been made since the Constitution became operative in 1980 , but they have not affected the Declaration of Rights (the bill of rights section). There has been no constitutional litigation on issues of equality for women, because the Constitution does not guarantee sexual equality or include a provision prohibiting sex-based discrimination. Interview with Alice Armstrong, Lecturer in Law, U of Zimb (Dec 18,1988 ). See May, Zimbabwean Women at 100-01 (cited in note 6), on the irony of Britain's role in drafting a constitution that did not include the guarantees of sexual equality that it had enacted for its own citizens.

In late 1988, President Mugabe and Joshua N'komo, head of the only significant opposition, announced the merger of their parties, which included representation in the government for N'komo and his party. While a small new opposition party has emerged, electing three members to Parliament in March 1990, Mugabe retains a vision of a one-party state. Zimbabwe Vote Tilts Toward One-Party Rule, Christian Science Mon 4 (Apr 5, 1990). The effect of such a development on the independence of the judiciary remains to be seen.

87 See Weiss, Women of Zimbabwe at 13-23, 105-11 (cited in note 1).

88 Andrew Ladley, Changing the Courts in Zimbabwe: The Customary Law and Primary Courts Act, 26 J African L 95, 109 (1982).

89 See Weiss, Women of Zimbabwe at 112 (cited in note 1).

90 The Act's passage was accompanied by a large public celebration. Weiss, Women of Zimbabwe at 112-15 (cited in note 1). The Legal Age of Majority Act is the subject of continuing efforts by women's groups to educate women about their rights and responsibilities. The Zimbabwe Women's Bureau, the Women's Action Group (WAG), and the Zimbabwe German Society held a series of well-attended public workshops on women's legal status and legal rights in 1987. The WAG and the Women's Forum, a consortium of women's organizations in Zimbabwe, have continued the educational effort. See, for example, Speak Out/Taurail Khulumani (Magazine of the WAG; published in English, Shona, and Ndebele) 4-8, 19-22, 29. 30 (Oct-Dec 1988) (special issue on the Legal Age of Majority Act). 
For example, a woman no longer must assert a claim of legal emancipation, evaluated unpredictably on a case-by-case basis, ${ }^{91}$ in order to manage her life effectively if she leaves the family home to live on her own.

The Zimbabwe courts have interpreted the Legal Age of Majority Act expansively, supporting the concept of women's responsible adulthood in a variety of circumstances. The Supreme Court has allowed a married woman to sue in her own right for damages for her daughter's seduction (customary law claim for compensation for loss of virginity, traditionally brought by the male guardian), ${ }^{92}$ and a married woman's right to sue on her own behalf in a property dispute has been upheld. ${ }^{93}$ A woman over the age of 18 does not need a guardian's consent to marry. ${ }^{94}$ Furthermore, a woman's legal adulthood renders the payment of bridewealth irrelevant to the validity of her marriage; she can consent on her own, regardless of whether a financial transaction has been concluded by a guardian. ${ }^{95}$ And in the landmark inheritance case of Chihowa v Mangwende, the Zimbabwe Supreme Court held that daughters have inheritance rights equal to those of their brothers when a parent dies intestate. ${ }^{96}$

The opinion in Mangwende emphasized that with the right to inherit comes the responsibility to support the dependents of the deceased. The emphasis on the obligation to support dependents illustrates the comprehensive effect of the Age of Majority Act: it underscores the capacity of women to carry their full share of economic as well as personal responsibility in the family and in society.

The Age of Majority Act also gives women the legal capacity to sue for custody in their own right instead of through their families. ${ }^{97} \mathrm{~A}$ mother's capacity to care for her children on her own-implicitly dismissed in the customary law tradition of automatic award to the fatheris thus acknowledged..$^{98}$

Other legislative changes signify the altered view of women's status

91 See Welshman Ncube, Released from Legal Minority: The Legal Age of Majority Act in Zimbabwe, in Women and Law in Southern Africa 193, 196-97 (cited in note 3).

92 Id at 197 (cited in note 91).

93 Id at 197-98.

94 Id at 202-03.

95 Id.

96 Chihowa v Mangwende, Judgement No S C 84/87; Civ App No 420/85 (Zimbabwe Sup Ct, July 7 and Aug 4, 1987).

97 Mary Maboreke, The Love of a Mother: Problems of Custody in Zimbabwe, in Women and Law in Southern Africa 137, 151-52 (cited in note 3).

98 In most customary law systems, a woman's parents maintain custody of her offspring until the bridewealth is paid; once it is paid, the father and his family have an unequivocal right to custody. See Gelfand, The Shona Woman at 42 (cited in note 74); Gita Monwana Welsh \& Albie Sachs, The Bride Price, Revolution, and the Liberation of Women, 15 Int J Soc of $\mathrm{L} 369$, 371,380 (1987). If bridewealth is no longer required in order to make a valid marriage (where a woman over 18 can consent to marriage irrespective of bridewealth), it no longer can be the determining factor in a custody dispute, and other factors such as the best interest of the children will carry some weight. This gives women a better chance to win a custody fight. This result is implicit as well in the Tanzania Law of Marriage Act (1971), which pro- 
in post-independence Zimbabwe. The Customary Law and Primary Courts Act, 1981, provides that a father must pay support ("maintenance") for his child. This provision gives women a better chance to fight for and win custody because it removes some of the economic barriers. ${ }^{99}$ In addition, the Matrimonial Causes Act, 1985, explicitly provides that the value of a housewife's contribution to marital property shall be considered in dividing the marital assets upon divorce. ${ }^{100}$ While this does not guarantee an award of half the property, it is a clear acknowledgement that women's labor is competent adult labor even if it is unpaid.

The legal changes in Zimbabwe since 1982 may not transform society immediately, but transformation would be impossible without them. In a country in which $96 \%$ of the women are African, ${ }^{101}$ heretofore subject to customary law, the implications of the changes are enormous. By declaring all women over the age of 18 to be adults, regardless of their racial or marital identity, Zimbabwe has provided the essential foundation on which equality rests.

\section{Jamaica: De Facto Disabilities}

Women in the Commonwealth Caribbean do not labor under the severe legal disabilities of African women subject to customary or religious law. Their status is limited instead by the de facto disabilities that result from social and economic invisibility. The frontier of equality isas it is in many other places-family and personal status law. Law reform activity concerning the status of Jamaican women has focused primarily on issues of equality in the family. In its treatment of equality, the Jamaican Constitution resembles those of Kenya and Zimbabwe. ${ }^{102}$ It guarantees sexual equality only in the exercise of fundamental freedoms, and its nondiscrimination provision excludes personal and family law matters and does not prohibit sex-based discrimination. ${ }^{103}$ Still, married Jamaican women have full rights to own and dispose of their property under the Married Women's Property Act; ${ }^{104}$ women who have

vides that bridewealth is not required in order to validate a marriage, $\S 41$, and that the "welfare of the child" shall be a "paramount" factor in determining custody, $\S 125(2)$.

99 Maboreke, The Love of a Mother: Problems of Custody in Zimbabwe, in Women and Law in Southern Africa at 151 (cited in note 3).

100 Zimbabwe Matrimonial Causes Act, § 7(3)(e) (1985).

101 Maboreke, The Love of a Mother, in Women and Law in Southern Africa at 138 (cited in note 3).

102 See notes 40 and 86 , on Commonwealth constitutions.

103 Jamaica Const, $\S \S 13,24$. As in the other Commonwealth countries with this type of constitution, the possibility of constitutional litigation of issues concerning women in the personal law context is foreclosed by these provisions. Jamaica remains a two-party democracy with a clearly independent judiciary. See Lloyd G. Barnett, The Constitutional Law of Jamaica 32124 (Oxford U Press, 1977).

104 Jamaica Married Women's Property Act, $\S \S 2,3$ (1987). 
reached the age of majority may marry without the consent of a guardian; ${ }^{105}$ and women's role in the paid labor force has been acknowledged in several legal provisions. ${ }^{106}$

Jamaica's Constitution gives greater citizenship rights to men than to women in that alien spouses of Jamaican men can become Jamaican citizens more easily than can alien spouses of Jamaican women. ${ }^{107}$ The failure to grant women equal capacity to confer citizenship on their spouses implies that women's citizenship is somehow less than complete. The Law Reform Commission recommended that the Constitution be amended to provide men and women with equal capacity to confer citizenship on their spouses. When Jamaica ratified the Convention on the Elimination of All Forms of Discrimination Against Women in 1984, it reserved Article 9(2), concerning equal nationality rights, because of the constitutional provisions on citizenship. Unlike most other countries that have ratified with reservations, Jamaica has indicated that it intends to make the necessary constitutional change so it can withdraw the reservation. ${ }^{108}$

The Jamaican Law Reform Commission has been working for several years on changes in family law, reflecting a growing understanding of the economic role of women in the family. In 1984 it issued a Working Paper on Matrimonial Law Reform that acknowledged in unequivocal terms the unpaid economic contribution of homemaker spouses and the role of wives in the family economic unit. ${ }^{109}$ The Commission already had recommended that the unpaid contribution of a homemaker spouse be considered in dividing the marital property and that the family home be determined to belong equally to both spouses regardless of the financial contribution of each. ${ }^{110}$ The Commission's position is that women's real contribution to the value of family property should be acknowledged even where it cannot be traced in monetary terms. The Commission has actively promoted this change, and its secretary reports

105 Jamaica Marriage Act, $\S 24$ (1973).

106 Legislation acknowledging the working life of women includes the Maternity Leave Act (1979); National Insurance (Amendment) (No 2) Act, $\$ 20 \mathrm{~A}$ (1979) (extending maternity pay to domestic workers); the National Minimum Wage (Amendment) Order, $\S 5$ (1984) (including household workers in minimum wage provisions); and the Employment (Equal Pay for Men and Women) Act, $\S \S 2,3$ (1975) (requiring equal pay for men and women engaged in equal work, defined as work having similar or substantially similar duties, conditions, degrees of skill, effort, and responsibility). This legislation is crucial to women's and children's economic well-being because one-third of the households in Jamaica are headed by women. See Joycelin Massiah, Women Who Head Households, in Joycelin Massiah, ed, Women and the Family 62, 104 (Inst of Soc and Econ Res, U West Indies, Barbados, 1982).

107 Jamaica Const, § 4.

108 Initial Reports of States Parties: Jamaica, 14-15 (UN Doc No CEDAW/C/5/Add 38, 1986); UN Committee on the Elimination of Discrimination Against Women, Seventh Session: Draft Report of the Committee (UN Doc No CEDAW/C/L3/Add 9, 1988).

109 Jamaican Law Reform Commission, Family Law Committee Working Paper on Matrimonial Property Reform 5-6 (1984).

110 Jamaican Law Reform Commission, Green Paper on Proposals of the Family Law Committee, Interim Report 14-17 (1977). 
that legislative change is probable. ${ }^{11}$

Commonwealth Caribbean women have had greater access to educational and paid employment opportunities than their African counterparts. ${ }^{12}$ They are somewhat more visible, but their place in adult society has yet to be fully acknowledged. The movement in Jamaica towards legal recognition of women's full participation as citizens and their economic role in the family is a positive movement towards equality.

\section{Canada: A New Charter for Equality}

Canada is an example of a post-industrial society in which the basic issues of women's legal capacity have long been settled, and the debate has shifted from issues such as legal recognition (e.g. legal capacity, right to own and dispose of property, right to child custody) to more subtle questions of workplace equity and gender equality in foreign aid programs.

The Canadian Charter of Rights and Freedoms, Canada's recently adopted bill of rights, includes two sections that guarantee equality. ${ }^{113}$ Section 15(1) is a general guarantee of "equal protection and equal benefit of the law without discrimination and in particular, without discrimination based on race, national or ethnic origin, colour, religion, sex, age or mental or physical disability." Section 15(2) allows for affirmative action to "ameliorate" the effects of discrimination. ${ }^{114}$ Section 28 states: "Notwithstanding anything in this Charter, the rights and freedoms referred to in it are guaranteed equally to male and female persons."115

The existence of two sections guaranteeing sexual equality-an unusual, if not unique, constitutional statement-is the result of the political activity surrounding adoption of the Charter. As part of a compromise to settle disagreements between the provincial and federal governments and between the provinces, ${ }^{116}$ certain provisions of the original draft Charter, including Section 15, were designated optional. Parliament or a provincial legislature could pass a law contrary to the Charter provision and declare that the provision could not be applied to invalidate the

111 Interview with Dr. Eileen Boxill, Jamaican Law Reform Commission (Nov 9, 1987).

112 As of 1978, women constituted $49 \%$ of Jamaica's paid labor force. Victoria Durant Gonzalez, The Realm of Female Familial Responsibility, in Massiah, Women and the Family 8 (cited in note 106). In contrast, only $18 \%$ of the Kenyan formal (wage) sector was composed of women in 1982. Women of Kenya: Review and Evaluation of Progress 33, 35 (Republic of Kenya, 1985). The female literacy rate in Jamaica is $95 \%$, while that of Kenya is $49 \%$. Ruth Leger Sivard, Women: A World Survey 39, 41 (World Priorities, 1985).

113 Canadian Charter of Rights and Freedoms (1982); see generally, Edward McWhinney, Canado and the Constitution 1979-1982: Patriation and the Charter of Rights (U of Toronto Press, 1982).

114 Canadian Charter of Rights and Freedoms, $\S 15(2)$ (1982). See also, Ann Bayefsky, Defining Equality Rights, in Equality Rights and the Canadian Charter 1, 3-12 (cited in note 1).

115 Canadian Charter of Rights and Freedoms, § 28 (1972).

116 See McWhinney, Canada and the Constitution at 90-97, 106 (cited in note 113). 
law. ${ }^{117}$ In addition, Section 15 was not to take effect until three years after the effective date of the remainder of the Charter. ${ }^{118}$

The addition of Section 28 , specifically guaranteeing sexual equality without the possibility of override by federal or provincial legislatures, was the direct result of organizational and political activity by Canadian women. Its existence is a tribute to their sophistication and a lesson to the predominantly male government officials who drafted and ultimately adopted the Charter. ${ }^{19}$ It also is a case study in the creation of political will illustrating the necessity of organization and communication to demonstrate the strength of the female constituency.

As Canada develops its standards under the Charter through judicial decisionmaking, its legal community has a unique opportunity to shape the equality discussion with a new language. ${ }^{120}$ That language could be creatively based in the concept of equality in terms of the extent to which society views men and women as equally participating adults. Under this scheme, the American jurisprudence of equal opportunity would be rejected in favor of examining equality issues on the basis of whether women are in a position to take advantage of opportunity when it is available. ${ }^{121}$ For example, a remedy for exclusion from particular job categories that traditionally have been male-dominated might include allowing experience credit for time spent in volunteer organizations or for development of skills in traditionally female jobs that appear on their face to be unrelated.

117 Canadian Charter of Rights and Freedoms, $\S 33$ (1972).

118 Id, § 32(2).

119 The events that resulted in inclusion of gender in the Charter's equality provisions are documented in de Jong, Sexual Equality: Interpreting Section 28 at $494-512$ (cited in note 1). The account suggests that certain government officials underestimated both the determination and the political skills of the concerned women.

120 Since 1982 legal scholars have made many suggestions as to standards that may be developed under the Charter. Comparisons have been drawn to American constitutional law, and standards of equality in international law have been invoked. See Walter S. Tarnapolsky, The Equality Rights, in Walter S. Tarnapolsky \& Gerald-A. Baudoin, eds, The Canadian Charter of Rights and Freedoms: Commentany 395, 395-407 (Carswell, 1982); Anne F. Bayefsky, The Principle of Equality or Non-Discrimination in International Law: Implication for Equality Rights in the Charter, in Lynn Smith, et al, eds, Righting the Balance: Canada's New Equality Rights 117 (Canadian Human Rights Reporter, 1986).

As of November 1989, no litigation under the gender equality provisions has reached the Supreme Court. Several provincial courts have decided cases under sections $15(1)$ and 28 , but the reports indicate that no new ground has been broken. The Supreme Court has yet to decide a sex discrimination case. See, for example, notations in Canadian Charter of Rights Annotated, § 15(1) (Canada Law Book, current to Nov 1989).

121 See Sheppard, Equality, Ideology, and Oppression at 215-19 (cited in note 13), suggesting that judicial decisionmaking take into account women's essential societal inequality; Anne F. Bayefsky, The Orientation of Section 15 of the Canadian Charter of Rights and Freedom, in Joseph Weiler \& Robin Elliot, eds, Litigating the Values of a Nation: The Canadian Charter of Rights and Freedoms 105, 112-16 (Carswell, 1986), concluding that the new provisions guarantee equality in a much broader sense than does the U.S. equal protection guarantee. Marc Gold has explicitly called for a new dialogue and new research centers that would explore these issues. See his Moral and Political Theories in Equality Rights Adjudication, in Litigating the Values of a Nation 85, 98 (cited in this note). 
The determination of whether women and men have been treated equally in terms of educational or employment opportunities might include consideration of the aspects of traditional socialization that have precluded women from seeking certain kinds of education or employment, and remedies might include valuation of the abilities developed by traditional socialization. For example, a claim of unequal treatment in a company or an academic track dealing with the hard sciences could be supported by statistical and other data on educational tracking and on the undervaluation of observation and communication skills that are traditionally emphasized in women's socialization. A remedy would include redrawing job descriptions and evaluation criteria to recognize the value of these skills in a new context.

Many important aspects of de facto capacity have been addressed in Canada by legislation, such as laws providing for pay equity ${ }^{122}$ and for homemakers' property rights upon divorce. ${ }^{123}$ A Human Rights Commission reviews legislation and activities and makes annual recommendations for legislative change to open more opportunities to women and minorities. ${ }^{124}$ In 1986 the Human Rights Commission recommended that the 1986 Employment Equity Bill, which provided for a major effort to move towards equity in the workplace, be amended prior to its passage to provide for better reporting and enforcement. ${ }^{125}$ Accordingly, it was amended. The Commission also promulgated guidelines in 1986 for pay equity in certain federal jobs. ${ }^{126}$

In 1985 the Minister of Justice produced a report entitled "Equality Issues in Federal Law," and the House of Commons established a Subcommittee on Equality Rights that held hearings throughout the country and issued a set of recommendations. ${ }^{127}$ The Subcommittee on Equality Rights made several recommendations concerning women's roles. It suggested that maternity benefits be equalized throughout the federal sector and that parental leave, provided through the unemployment insurance scheme, be provided to men and women on an equal basis. ${ }^{128}$ It also suggested major changes in the federal pension plan to give women equal standing with men in terms of collection, including splitting of a couple's credits when they separate or divorce and elimination of sexbased mortality tables. ${ }^{129}$

\footnotetext{
122 Canada Human Rights Act, Ch 33, § 11 (1976-77).

123 Carol Mahood Huddart, Property Division on Marriage Breakdown in the Common Law Provinces, Audrey Doerr \& Micheline Carrier, eds, Women and the Constitution in Canada 94, 95. 98 (Canadian Advisory Council on the Status of Women, 1981).

124 Canada Human Rights Act, Ch 33, § 27, 61 (1976-77).

125 Canadian Human Rights Commission, Annual Report 1986 at 11 (Canada, 1987); see Employment Equity Act, Stat Can, Ch 31 (1986).

126 Annual Report 1986 at 13 (cited in note 125).

127 Toward Equality: The Response to the Report of the Parliamentary Committee on Equality Rights at 7 (Canada, 1986).

128 Id at 7-8.

129 Id at $19-23$.
} 
The issues raised by the Human Rights Commission and the Subcommittee on Equality Rights suggest that while the frontier of equality may shift, the essential questions remain the same. The focus of the equality effort always must be to permit and promote the movement of women into their adult roles, to allow women to make individual choices without being legally or culturally hampered by biases or mistaken perceptions of their capabilities.

The long-term practical effects of Canada's constitutional guarantees of equality remain to be seen. At this point Canada stands as an example of a post-industrial country that has exhibited a considerable degree of political will to deal with basic questions of women's adult capacity even before developing constitutional standards for measuring equality.

\section{CONCLUSION}

Constitutional guarantees of equality are mere paper and print unless leaders and citizens demonstrate the political will to acknowledge women as full adult participants in their society. Indeed, in many Commonwealth countries, such as Kenya, Zimbabwe, and Jamaica, progress towards equality has been made despite a lack of specific equality provisions in the constitution.

In measuring progress towards equality, we must look not only at constitutions but at the premises of legal and policy changes that affect women. Changes that are premised on explicit or implicit recognition of women's full adult roles-as paid and unpaid workers, as managers of household finances, as people entrusted with guiding children toward adulthood-constitute positive recognition of women's capacities.

Historically, the initial battleground of legal change to recognize women's capacities has been that of family law, because the legal definition of women's status as individuals has traditionally been based on their family and marital status. In the Commonwealth African countries, in which most women traditionally have been treated as perpetual minors according to customary law, significant equality issues have been framed as questions of women's status as family members; legal reforms that recognize women's rights to consent to marriage, to inherit property, and to have custody of children thus represent progress. In countries such as Jamaica and Canada, where for decades women have had specific rights to legal adulthood regardless of family or marital status, reform efforts have focused on the right to equal pay for equal work and on family law provisions that more fully recognize women's unpaid contribution to family property. In all of these countries the objective of reform remains the same: recognition of the full value of women's paid and unpaid contributions to their economy and their culture. 
The concept of capacity may be used to measure progress in every instance in which women and men, governments and individuals, seek change to improve the status of women. Progress towards equality requires that women and men see themselves-equally-as adults contributing together to the foundation and the future of their society. 